DOI: https://doi.org/10.35619/prap_rv.vi12.60

\title{
ТРАКТУВАННЯ ЯВИЩ СУСПІЛЬНОЇ ЄДНОСТІ В СУЧАСНІЙ ПСИХОЛОГІї
}

Стаття присвячена аналізу сучасних підходів до дослідження понять про єдність суспільства, представлено конструкти соиіальної єдності, консолідації та солідарності. Встановлено зв'язки та відмінності психологічної сутності явищ. Обтрунтовано актуальність дослідження проблем єдності суспільства в сучасній науці, представлено рівень розробленості конструктів та окреслено нерозв 'язані аспекти проблеми, щุо стануть предметом наших подальших розвідок.

Ключові слова: консолідаџія, солідарність, групова поведінка, інтеграція, ідентифікація, ідентичність, благополуччя, сочіальний капітал.

Статья посвящена анализу современных подходов $к$ исследованию понятий о единстве общества, представлены конструкты социального единства, консолидации и солидарности. Установлень связи и отличия психологической сути явлений. Обоснована актуальность исследований проблем единства общества в современной науке, представлен уровень разработанности конструктов и очерчены нерешенные аспекты проблемы, которые станут основой наших дальнейших исследований.

Ключевые слова: консолидация, солидарность, групповое поведение, интеграция, идентификачия, идентичность, благополучие, социальный капитал.

Постановка проблеми: Внаслідок світової тенденції до зростання культурного, етнічного різноманіття, економічної нерівності проблемами єдності суспільства починає цікавитись все більша кількість дослідників. Зокрема, до ії вирішення звертаються Європейський союз, Рада Європи, Організація економічного співробітництва та розвитку (ОЕСР), Асоціація держав Південно-Східної Азії (АСЕАН), роблячи запити на дослідження процесу і механізмів єдності суспільства.

Аналіз останніх публікацій свідчить про інтенсивну розробку поняттєвого апарату проблеми, зокрема йдеться про: соціальну єдність (Ботерман С., Дікес П., Дженсон Д., Мемолі В., Прідхам Г., Стоун В., Халс К., Харел А., Чан Д.), консолідацію (Бакіров В., Козловець М., Локосов В., Лубський В., Луцишин Г., Майборода О., Шульц В.), солідарність (Горшков М., Зайцев Д., Зайцева О.,Сорокін П., Строеб К., Окатов О.). 3 усім тим, вони здебільшого вживаються як взаємозамінні, оскільки розробляються в різних методологічних традиціях таких як соціологія, психологія, політологія, культурологія, філософська антропологія, соціальна філософія, релігієзнавство.

Формулювання цілей статі. Теоретичний аналіз сучасних підходів щодо психологічного змісту й структури понять у трактуванні соціальної єдності.

Виклад основного матеріалу: У зарубіжних дослідженнях найбільше вживаним у трактуванні консолідації суспільства $€$ поняття «social cohesion» (соціальна єдність, узгодженість, послідовність, злагодженість, згуртованість).У суспільно-політичній практиці (зокрема, запит Федерального правління Канади в 1996 р.) проблема соціальної єдності актуалізувалася у зв'язку 3 неможливістю існуючих наукових розробок запропонувати коректне їх розв'язання. В основному парадигми орієнтовані на врахування економічної і політичної складової функціонування суспільних груп. Соціальні взаємовідносини, які позначалися поняттями соціального успіху/невдачі, соціальної інклюзії, благополуччя, громадянства, ідентичності, культурного розвитку, рівня доходу залишалися поза існуючими парадигмами і програмами досліджень $[16$, с.6]. Водночас, зміст явища соціальної єдності визначається як побудова спільних цілей, зменшення розриву у благополуччі, доходах, $\mathrm{i}$ можливість людей почуватися залученими до структури єдності, вирішувати спільні проблеми i відчувати, що вони є членами одного об'єднання (Дж. Максвел, 1996 р.).

У п’ятивимірному конструкті соціальної єдності, в основу закладено дихотомії понять: 1) афіліація/ізоляція (спільні цінності, відчуття приналежності до одного суспільства); 2) інтеграція/відчуження (справедливість розподілу економічних благ); 3) участь/пасивність (залученість до вирішення громадських питань); 4) прийняття/відторгнення (толерантність по відношенню до відмінностей); 5) легітимність/нелегітимність (підтримка громадських та приватних інститутів, які виступають в якості медіаторів, тобто те, наскільки повноцінно різні інститути представляють людей та їх інтереси). [10, с. 453]. Більшість дослідників погоджуються із багатоаспектністю соціальної єдності. Найчастіше йдеться про такі iї виміри: соціальні стосунки та 
мережі, соціальна та політична довіра, толерантність, громадянська позиція, політична участь та відсутність конфліктів у державі (Валентова М., Джанмат Г., Дікс П., Чан Д.).

У сучасних емпіричних розвідках йдеться про спроби визначення: особливостей суспільств, які характеризуються єдністю (Валентова М.,Дікс П.,2013); умов в країні, які посилюють чи ослаблюють соціальну єдність (Джанмат Г. 2011, Bertelsmann-Foundation, 2013) тощо. У 2011 р. в Організації економічного співробітництва та розвитку (ОЕСР) соціальну єдність визначено як міру, якою суспільство «працює заради благополуччя всіх членів, бореться 3 маргіналізацією та виключенням, створює відчуття приналежності, поширює довіру і пропонує учасникам «соціальний ліфт» [14, с.2] (перехід від нижчого класу чи статусу до вищого). У 2015 р. здійснено спробу узагальнити та систематизувати різні змісти щодо трактування конструкту соціальної єдності (Дільхея Д., Драголова Г.). Дослідження та порівняння конструктів соціальної єдності та соціального капіталу свідчить, що соціальна єдність $є$ ширшим поняттям, яке вмішує і соціальний капітал (Дженсон Д., Кернс А., Кляйн К., 2013 р.).

Поняття зв'язаності (Connectedness) стосується вертикальних зв'язків між індивідами та державними інститутами. Суспільство соціальної єдності неможливе без необхідного і достатнього розвитку міри довіри не лише по відношенню до інших людей, але й стосовно державних інститутів (Дікс П., Усланер М., Чан Д.). Орієнтація на спільне благо відображається в діях і ставленні учасників суспільства, що демонструє відповідальність по відношенню до інших та до суспільства в цілому. Йдеться про солідарність, повагу до законів та громадянську участь $[13$, с.2]. Громадянська участь $\epsilon$ відображенням почуття приналежності, солідарності та готовності до кооперації з метою досягнення спільних цілей.

Дослідники зазначають, що соціальна єдність має три основні характеристики: а) стійкі соціальні зв’язки, б) позитивний емоційний контакт між учасниками суспільства та в) зосередження на досягненні спільного блага. Соціальні стосунки передбачають горизонтальні і вертикальні зв'язки [13], що відповідають першому та п’ятому вимірам у вищезгаданому конструкті єдності за Джейсон Д.

Як бачимо, в дослідженнях, присвячених соціальній єдності, іiі зміст грунтується на позиції єдності суспільства загалом, тобто відмінною рисою соціальної єдності є іiі масштабність. Йдеться про включення до єдності всіх можливих груп-представників суспільства. Соціальні стосунки охоплюють взаємини між різними групами в суспільстві: культурними, етнічними, релігійними, професійними, демографічними, політичними та ін.(Нолл Д.,Шіфер Д.). Соціальна єдність вимагає від представників різних груп взаємної толерантності [15]. Отже, соціальна єдність не є продуктом індивідуальної поведінки, а детермінується спільними цінностями, кооперацією та взаємодією (Рада Європи 2005, Грін А., Джанмат Г.).

Консолідація також основана на спільних цінностях та взаємодії, проте у її дослідженнях не завжди враховується взаємодія суспільства в цілому. Так виокремлюють види консолідації: національна, соціальна, політична, етнічна, громадянська (Луцишин Г.). Вона може бути різною за масштабами і функціонувати як на національному (суспільному) рівні, так і на рівні груп, коли йдеться про політичну, громадянську, соціальну консолідацію. Недарма Філіппов О., зсуваючи солідарність у площину групової взаємодії, ставить питання про можливість ії розгляду через солідарність протесту. У такому випадку йдеться про пасіонарні рухи та об'єднання, метою яких $\epsilon$ відстоювання власних інтересів, та цілей. Мотивами об'єднання таких груп переважно є ціннісні, ідеологічні, ідейні, духовні і т.д.

Враховуючи множинність структур і об'єднань у суспільстві, різний етнічний (демографічний та ін.) склад, вважають, що консолідація як процес виникає між групами однодумців навколо політичних, етнічних лідерів чи проти них (наприклад, консолідація політичної опозиції під час виборів) [5, с.36].

Участь у соціальних рухах передбачає наявність відчуття солідарності в їхніх учасників. Вони долучаються до рухів, об'єднань, коли розділяють ентузіазм, прихильність до групи тощо. В основі залучення $є$ колективізм та відчуття ідентичності з групою. Колективна ідентичність $є$ конструкцією, що містить когнітивні, емоційні та моральні зв'язки з групою чи рухом. Бенфорд Р. та Ханд С. наголошують на важливості прихильності та колективної ідентичності в становленні і утриманні консолідації групи. Колективна ідентичність представлена трьома елементами: межі, усвідомлення та готовність до переговорів/діалогу [12].

Завдяки елементу «межі» встановлюється відчуття відмінності «моєї» групи від іншої. Межі встановлюють кордони, соціальну територію групи, впроваджуючи моральні, когнітивні, афективні, поведінкові та інші відмінності між учасниками даного соціального руху та іншими. Межі 
конструюють динаміку колективної ідентичності. Ритуали, присвячені закріпленню меж, посилюють внутрішню солідарність (Тайлором Б.).

Окрім впровадження відчуття «ким ми є», з'являється також відчуття «ким ми не є». Таким чином, межі конструюють ідентичність учасника групи, відчуття «ми-вони». Поруч 3 відчуттям приналежності сутнісними вважають соціальну взаємодію, довіру та готовність до участі, допомоги (Чан Д.). Інші дослідники вважають, що ідентифікація з групою породжує дискримінацію відносно до інших груп, сприяє зростанню неприйняття їх учасників, що підігріває ворожість, дискримінацію та підсилює відчуття ідентичності зі своєю групою (Льюіс В.). Проте, так відбувається не завжди. Якщо відмінності оцінюються позитивно, наприклад, як збагачення варіативності,яка підтверджує погляди групи, то вони будуть прийняті (Вензел М.).

По-суті, йдеться про двояке значення міжгрупових відмінностей. 3 одного боку, відмінність між групами може збільшити мотивацію для встановлення позитивної самобутності через диференціацію. 3 іншого ж боку, ця сама відмінність може стати основою для закріплення негативного ставлення по відношенню до інших, коли різниця сприймається як відхилення, неповноцінність, неправильне сприйняття світу i, відповідно, становить загрозу для поглядів групи, релевантних iї ідентичності цінностей. Різниця, що сприймається групою, може мати два протилежних впливи: один опосередковується мотивацією (підтримка позитивної відмінності), а інший - легітимацією (захист особисто значущих цінностей) (Мамменді А., Венцел М.). Проте було б невірним стверджувати, що мотивація та легітимація $є$ незалежними одна від одної. Будучи мотивованими на встановлення позитивної групової відмінності, учасники групи можуть конструювати суб'єктивно достатню легітимацію для зовнішньо групового антагонізму.

Усвідомлення забезпечує визначення та визнання інтересів групи. У контексті політичних рухів це означає розвиток політичної свідомості чи «опозиційної свідомості» [12,с.442]. Готовність до переговорів передбачає узгодження дій і шляхів активного виявлення позиції групи. Соціальні рухи виникають через неузгодженість, суперечливість інтересів у суспільстві, через конфліктність преференцій відносно розподілу та перерозподілу того, що вважається цінністю. Виділяючи основні позиції, за яких сучасні вітчизняні дослідники, залежно від виокремлення основної функції консолідації та її перспективних можливостей в реалізації, говорить про неї як про: позитивну форму організації (Пилявець Р., Луцишин Г.); взаємодію і згоду соціальних груп (Горшкова М.); чинник ефективних соціальних дій (Степико М.) [6].

Первинною умовою консолідації є усвідомлення потреби і їі вирішення [4]. Враховуючи таку умову, з позицій структурного функціоналізму консолідація може бути стихійною, виникнення якої провокується подією, миттєвою актуалізацією потреби; або ж умовно константною (пролонгованою), що основана на глибоких інтеграційних процесах і необхідності таким чином постійно підтримувати певний рівень задоволення потреб (Дюркгейм Е., Мертон Р., Парсонс Т, Спенсер Г.). Услід за Фроловим П., вважаємо, що консолідація є специфічним видом єдності, який полягає у готовності учасників до спільних дій та наявність в них спільної мети. Фролов П., досліджуючи консолідацію, виділяс їі види - нормативний і процедурний [8]. Про нормативну консолідацію йдеться, коли сутнісними є спільні ідеї, цінності, норми, почуття. Процедурна консолідація пов'язана з процесом вироблення спільного розуміння, спільного підходу до вирішення проблеми. Таким чином, ми маємо справу з різними шляхами інтеграції, де головними є принципи ідеї та досягнення консенсусу, який Конт О. представив у якості найвищого ступеня розвитку і специфіки соціальної солідарності.

Отже, однією 3 характеристик консолідації $€$ спільні для групи ідеї та цінності. Така консолідація є (за Дюркгаймом Е.), добровільною (органічною). Водночас іншим полюсом дихотомії консолідації є примусовий (механічний). Але навіть за механічної консолідації зовні суспільство може здаватись ідеально консолідованим, з єдиними цінностями та готовністю захищати ідеї. Проте відбувається це шляхом встановлення тоталітарного суспільства, в якому немає місця плюралізму та відмінностям.

Дослідники зазначають, що досягнення єдності всього суспільства є недосяжним результатом [3], оскільки це можливо лише за умов тоталітарного суспільства. Переважно акцентують увагу на парціальній формі єдності, що представлена своєрідними просторами єдності (та їхньою локалізацією), які $є$ системотвірними для суспільства [3, с.104]. 3 усім тим, залишається нерозробленою проблема критеріїв визначення таких просторів єдності всередині електоральних груп та між ними. У синонімічному ряді, дібраному до терміну «консолідація» вживається термін «солідарність». Основою дослідження солідарності $є$ соціальна ідентичність та міжгрупові стосунки (Дусджі Б., Еллемерс Н., Спірс Р.).

Солідарність вважають усвідомленням спільної мети й спільної відповідальності. Еволюція солідаризму полягає в переході від об'єднання на основі біологічної спорідненості до культурної та Випуск 12, 2019. Збірник наукових праць РДГУ 
політичної єдності [2]. Тому солідарність є вищим рівнем організації спільноти.Парсонс Т. пов'язує солідарність із соціальними ролями. Якщо особа належить до колективу, то вона має обов'язки, завдяки яким вона солідаризується 3 іншими членами суспільства. Вказуючи на недостатню релевантність теоретинчих положень Т. Парсонса стосовно сучаної суспільно-політичної практики, Філіппов О. визначає роль як певну позицію в соціальній системі, виконання комплексу очікуваних дій. Проте система потребує від людей не лише виконання необхідних дій, але і згуртованості [7, с.7]. Тому окрім функціонально узгоджених дій, солідарність передбачає спільне ставлення до цінностей, вираження емоцій і відчуття взаємної приналежності до одного колективу. Йдеться про уточнення або й трансформацію змісту поняття солідарності Сорен Дж. [11]. Зокрема, здійснено спроби соціологів виділити нові форми солідарності: афективна, конвенційна та відображуюча (Діан Дж.). Згідно із запропонованою класифікацією, афективна солідарність основана на близьких стосунках [11, с.256]. Соціальні зв'язки об'єднують індивідів у спільне почуття «ми», що $є$ афективним, тому солідарність не може бути розширена, щоб включати сторонніх, хто не входить до «ми»-конструкту.

Розглядаючи роль афективного компоненту, висвітлюють також можливість спільного переживання горя (ПостмесТ., Рус К.,Строеб К.). Йдеться про можливість розділити емоції, що $є$ способом подолання інтенсивного емоційного переживання. Це посилює відчуття солідарності [17, с.3]. У дослідженнях виявлено, що переживання нещастя, складних подій створює відчуття ідентичності у жертв. Відбувається ідентифікація саме з группами, а не з індивідами, коли йдеться про подолання стресових подій. Даний підхід розкриває важливість групової взаємодії для подолання негараздів у соціальному житті. Таким чином, групова поведінка спрямовується комунікацією 3 тими, хто переживає таку ж несправедливість. Така орієнтація на внутрішньогрупові стосунки може бути, на думку авторів, суттєвим кроком до формування відчуття «ми», в побудові спільного розуміння переживання стресової ситуації та відповідальності.

Конвенційна солідарність (основана на спільних інтересах) породжується традиціями i цінностями, що єднають групу, інколи детермуніється необхідністю об'єднати зусилля для боротьби. Всередині такої групи (яка функціонує на основі конвенційної солідарності), зазвичай $\epsilon$ встановленими норми, які застосовуються по відношенню до ії учасників. Таким чином, даний вид солідарності $\epsilon$ внутрішньою відповідальністю між учасниками відносно гомогенної групи.

Відображуюча солідарність є взаємнимочікуванням відповідальності у стосунках. Цей вид солідарності долає обмеження двох перших видів: відображуюча солідарність об'єднує членів ідеального суспільства. Очікується усвідомлення взаємозалежності, властивої учасникам в окремості вразливості та прийняття відносин один з одним (Діан Дж.). На думку Кернс А. та Форест Р., емоційна прив'язаність та відчуття приналежності вже $\epsilon$ вираженням людиною того, що вона поділяє цінності, стиль життя та контекст соціалізації [15]. Діан Дж. ставить під сумнів традиційні форми солідарності через їхню неможливість охопити сучасне суспільство як інтегроване об'єднання людей зі спільними цілями. Оскільки в суспільстві панує індивідуалізм і ціннісний плюралізм, виникає потреба в інклюзивній концепції солідарності, яка охоплює людей, що відрізняються від більшості. Зокерма, у теорії визнання (Хонет А.), визнання є передумовою розвитку добре функціонуючої соціальної ідентичності та, відповідно, можливостей людей щодо самореалізації, участі та інтеграції [11]. 3 такої точки зору, солідарність стає питанням організації суспільства таким чином, щоб забезпечити кожному рівне право на досягнення визнання. Запозичивши ідею у Г. Гегеля, Хонет А. зазначає, що благополуччя людини пов'язане із взаємним визнанням та виокремлює відмінності потреб для визнання: у формі любові, правове, емоційне прийняття (солідарність).

Визнання у формі любові забезпечує можливість розвивати позитивні стосунки, що надають людині впевненості і дозволяють їй діяти, спілкуватися і бути частиною об'єднань. Правове визнання громадян як рівних учасників суспільства, виникає на засадах права і рівного, справедливого юридичного вирішення проблем. $\mathcal{E}$ вирішальним фактором у можливості людини брати участь в соціальному житті на засадах рівних 3 іншими правами. Рівні права і доступ до інформації, можливість бути почутим робить суспільство більш інтегрованим. У цьому випадку принципово важливо розрізняти формально проголошувані права та їх фактичне втілення і дотримання, оскільки задекларовані постулати і реальний досвід громадян в їхреалізаціїє відмінними. Солідарність чи соціальне прийняття є однією з передумов розвитку самооцінки. Йдеться про прийняття людини з іï особливими якостями. Цезабезпечує людину відчуттям безпеки та породжує в ній ресурси позитивного ставлення до себе (Елемерс Н., Оуверкерк В.).

Проте, якщо розглядати солідарність як прийняття інших, то постає питання щодо відмінності, в такому випадку, між солідарністю та толерантністю? У співвідношенні солідарності і толерантності (лояльності) ПарсонсТ. вважає, що цінності можуть бути когнітивними стандартами, що керують комунікацією (говорячи про солідарність), але моральні стандарти інтеграції $\epsilon$ 
наступним, більшвищим і складнішим рівнем відповідальності учасників за цілісність системи (толерантність). Він відрізняе солідарність від толернтності, розглядаючи солідарність в якостіпередумови толерантності. Близькими до солідарності є поняття, які виокремлює Гофман О.: погодження, зв'язок, інтеграція, асоціація, союз, співдружність, спільність, кооперація,об'єднання, взаємодопомога, обмін, милосердя, благодійність [2]. Співвідносячи зазначений синонімічний ряд щодо солідарності із синонімічним рядом, запропонованим Фроловим П. [8, с. 239] стосовно поняття консолідації, можна виокремити спільність змісту як з боку структурних, так і функціональнопроцесуальних складових, 3 використанням яких описуються явища. Тому у наших дослідженнях консолідація та солідарність $є$ взаємозамінними поняттями, тоді як соціальна єдність відрізняється за своїм функціональним значенням і можлива лише на найвищому рівні об'єднання людей - на рівні суспільства.

Висновки та перспективи подальших розвідок. Аналіз змісту конструктів щодо трактуванні поняття консолідації групи свідчить, що соціальна єдність, консолідація, солідарність $\epsilon$ видами суспільної єдності. Соціальна єдність $є$ найбільш широким поняттям та передбачає дослідження даного явища на рівні суспільства. У соціальній єдності на перший план виступають соціальні стосунки, соціальна довіра, орієнтація на досягнення спільного блага. Дослідження соціальної єдності на індивідуальному чи груповому рівні неможливе, на відміну від консолідації (солідарності). Соціальна єдність $\epsilon$ відносно стабільною та стійкою, тоді як групова консолідація може виникати стихійно і характеризуватися недовготривалістю. У консолідованого, солідарного об'єднання має бути спільна мета та виражена готовність діяти задля ії досягнення. Відносно соціальної єдності ми вживаємо поняття «спільне благо», яке не має чіткої, досяжної за певний проміжок часу мети, а $є$ елементом для підтримки комфортного життя членів суспільства. Однією 3 умов соціальної єдності $є$ довіра громадян та легітимність державних інститутів. У випадку 3 консолідацією, вірним є і протилежне: угрупування можуть формуватися і на основі недовіри до влади та прагнення відстояти відмінні від запропонованих цілі.

У плюралістичних суспільствах спостерігається певний рівень конфліктності та розділення, коли викорінення групової солідарності є умовою виникнення тоталітарного режиму. Солідарність (тобто, коли вона одна) $є$ передумовою тиранії. Сучасне суспільно-політичне життя України має суттєвий рівень розділення суспільства, що з'ясовано дослідженнями вітчизняних вчених (І.Белешкіна, С.Головаха, Ю.Тищенко). Тому наші подальші наукові розвідки будуть спрямовані на дослідження консолідаційних процесів груп, що утворились внаслідок такого роз’єднання.

\section{Список використаних джерел}

1.Арендт Х. Истоки тоталитаризма / Х. Арендт; пер. с англ. : И. В. Борисовой, Ю. А. Кимелева, А. Д. Ковалева и др. под ред. М. С. Ковалевой, Д. М. Носова. - М. : ЦентрКом, 1996. $-672 \mathrm{c}$.

2.Гофман А. Солидарность или правила, Дюркгейм или Хайек? О двух формах социальной интеграции / А. Гофман // Социологический ежегодник 2012 : сб. науч. тр. / ред. : Н. Е. Покровский, Д. В. Ефременко. - М. : ИНИОН РАН ; Каф. общей социологии НИУ ВШЭ, 2013. - С. 97-167.

3.Зайцев Д. Социальная сплоченность: проблемы и ресурсы достижения / Д. Зайцев, 3. Дыльнова, Ю. Селиванова // Общественные науки. Социология. - 2016. - С. 113-123.

4. Левашов В. Российское общество и социальное знание / В. Левашов. // Мониторинг общественного мнения. - 2009. - № 3. - С. 26-50.

5. Луцишин Г. I. Национальная консолидация общества: теоретико-методологические проблемы исследования [Электронный ресурс] / Г. І. Луцишин / Нац. ун-т "Львов. политехника". Львов. - Режим доступа : http://archive.nbuv.gov.ua/Portal/.../SL5_doc.pdf

6. Петухова О. В. Консолідація: сутність і види [Електронний ресурс] / О. В. Петухова // Інвестиції: практика та досвід. - 2015. - № 3. - С. 130-135. - Режим доступу : http://nbuv.gov.ua/UJRN/ipd_2015_3_30.

7. Филиппов О. Мобильность и солидарность / О. Филиппов // Социологическое обозрение. 2011. - T. 10, № 3. - С. 4-19.

8. Фролов П. Громадська думка: критерії та моделі консолідації / П. Фролов // Наукові студії 3 соціальної та політичної психології. - Київ : Міленіум, 2014. - С. 234-244.

9. Delhey J. Happier together. Social cohesion and subjective well-being in Europe / J. Delhey, G. Dragolov // International Journal of Psychology. - 2015. - № 51 (3). - S. 163-176.

10. Dickes P. Construct Validation and Application of a Common Measure of Social Cohesion in 33 European Countries / P. Dickes, M. Valentova, M. Borsenberger // Social Indicators Research. - 2009. № 98. - S. 451-473. 
11. Juul S. Solidarity and Social Cohesion in Late Modernity: A Question of Recognition, Justice and Judgement in Situation / S. Juul // European Journal of Social Theory. - 2010. - № 13. - S. 253-269.

12. Hund S. Collective Identity, Solidarity, and Commitment [Electronic resource] / S. Hund, R. Benford // The Blackwell Companion to Social Movements. - 2007. - Access mode: doi:10.1002/9780470999103.ch19.

13. The connection between social cohesion and personality: A multilevel study in the Kyrgyz Republic [Electronic resource] / M. Larsen, D. Esenaliev, T. Bruck, K. Boehnke // International Journal of Psychology. - 2018. - Access mode : doi:10.1002/ijop.12551.

14. Ludin $\mathrm{S}$. The association between social cohesion and community disaster resilience: A cross sectional study / S. Ludin, M. Rohaizat, P. Arbon. // Health Social Care Community. - 2018. - C. 1-11.

15. Sciefer D. The Essentials of Social Cohesion: A Literature Review / D. Sciefer, J. Noll. // Social Indicators Research. - 2016. - №132. - C. 579-603.

16. Stanley D. What do we know about social cohesion: The Research Perspective of the Federal Government's Social Cohesion Research Network / D. Stanley. // The Canadian Journal of Sociology / Cahiers canadiens de sociologie, Vol. 28. - 2003. - №1. - C. 5-17.

17. Stroebe K. Where did inaction go? Towards a broader and more refined perspective on collective actions [Electronic resource] / K. Stroebe, T. Postmes, C. Roos // British Journal of Social Psychology. - 2018. - Access mode : doi:10.1111/bjso.12295.

\section{References}

1. Arendt H. Istoki totalitarizma / H. Arendt; per. s angl. : I. V. Borisovoj, Ju. A. Kimeleva, A. D. Kovaleva y dr. ; pod red. ; M. S. Kovalevoj, D. M. Nosova. - M. : CentrKom, 1996. - 672 s.

2. Gofman A. Solidarnost' ili pravila, Djurkgejm ili Hajek? O dvuh formah social'noj integracii / A. Gofman // Sociologicheskij ezhegodnik 2012 : sb. nauch. tr. / red. : N. E. Pokrovskij, D. V. Efremenko. M. : INION RAN ; Kaf. obshhej sociologii NIU VShJe, 2013. - S. 97-167.

3. Zajcev D. Social'naja splochennost': problemy i resursy dostizhenija / D. Zajcev, Z. Dyl'nova, Ju. Selivanova // Obshhestvennye nauki. Sociologija. - 2016. - S. 113-123.

4. Levashov V. Rossijskoe obshhestvo i social'noe znanie / V. Levashov // Monitoring obshhestvennogo mnenija. - 2009. - № 3. - S. 26-50.

5. Lucishin G. I. Nacional'naja konsolidacija obshhestva: teoretiko-metodologicheskie problemy issledovanija [Elektronij resurs] / G. I. Lucishin ; Nac. un-t "L'vov. politehnika". - L'vov. - Rezhim dostupu : archive.nbuv.gov.ua/Portal/.../SL5_doc.pdf

6. Petuhova O. V. Konsolidacija: sutnist' i vidi / O. V. Petuhova // Investiciï: praktika ta dosvid. 2015. - № 3. - S. 130-135. - Rezhim dostupu : http://nbuv.gov.ua/UJRN/ipd_2015_3_30

7. Filippov O. Mobil'nost' i solidarnost' / O. Filippov // Sociologicheskoe obozrenie. - 2011. T. 10, № 3. - S. 4-19.

8. Frolov P. Gromads`ka dumka: kry`teriyi ta modeli konsolidaciyi / P. Frolov // Naukovi studiyi z social`noyi ta polity`chnoyi psy`xologiyi. - Kyiv : Milenium, 2014. - S. 234-244.

\section{PSYCHOLOGY \\ S. I. Kravchenko DEFINITION OF THE SOCIAL UNITY PHENOMENON IN MODERN}

The article focuses on the analysis of approaches to the study of the concepts of the unity of society; constructs of social unity, consolidation and solidarity are presented, relevance of research of the problems of unity of society in modern science is justified, the level of elaboration of constructs and the unresolved aspects of the problem that will be the basis of our further research are presented.The connections and differences of the psychological essence of the phenomena are established, the problems of the intersection of the substantive elements of the concepts of social unity and the incorrect phenomena unification on the part of researchers are revealed. The multidimensionality of phenomena reveals the non-triviality of the stated problem, and this article is our first step for its further solution. This, in turn, will make possible the implementation of more efficient technologies of the social cohesion.

During the analysis of publications we have established that social unity is a stable characteristic of society, while phenomena of consolidation, solidarity of groups, which can occur spontaneously and exist for a short time are more common for conflict, atomized society. In addition, consolidated associations, as a rule, have a common, specific goal, for which they are ready to unite. When it comes to social unity, it is appropriate to talk about supporting the comfortable life of members of society and the opportunity to unite around abstract goals and values. It should be noted that the problems of social unity are being actively investigated in Europe and the USA, whereas in domestic spaces this problem is not given due attention, and that fact will determine the course of our further work. 
Key words: consolidation, solidarity, group behavior, integration, identification, identity, well-being, social capital.

УДК 159.9 - 796.03:[005.32:316.614]

DOI: https://doi.org/10.35619/prap_rv.vi12.61

\section{3. Ю. КРИЖАНОВСЬКА, С. МІРЧЕНКО}

\section{МОТИВАЦИЙНИЙ КОМПОНЕНТ САМОРЕАЛІЗАЦІЇ В СПОРТИВНІЙ ДІЯЛЬНОСТІ}

У статті здійснено аналіз мотивачійної детермінаиії самореалізаиії особистості в спорті. Окреслено специфіку спортивної діяльності. Ї̈ визначено, як універсальну сферу для повноцінної й органічної самореалізаиії особистості. Встановлено, що розвиток наукового розуміння феномену самореалізації належить представникам екзистенційно-гуманістичного напряму в філософії. Самореалізація розглядається як спосіб максимального самовиповнення себе у житті. Встановлено значущеість мотивачійних компонент особистості в процесі самореалізациї в спорті.

Емпірично доведено, щяо для більшості молодих спортсменів спорт $\epsilon$ сферою для самореалізації. Їхнє розуміння поняття “самореалізаиія” узгоджується з класичним його визначенням. 3 'ясовано, щз мотивація у різних груп спортсменів різниться за змістом. Мотиваційна детермінація самореалізованих в спорті волейболістів відображає зміст та характеристики спортивної діяльності.

Ключові слова: спорт, мотивачія, самореалізачія, спортивна діяльність, волейбол.

В статье осуществлен анализ мотиващионной детерминации самореализации личности в спорте. Определено специфику спортивной деятельности. Она определена, как универсальная сфера для полноценной и органической самореализации личности. Установлено, что развитие научного понимания феномена самореализачии принадлежит представителям экзистенциальногуманистического направления в философии. Самореализащия рассматривается как способ максимального самовиповнення себя в жизни. Установлено значимость мотивационных компонент личности в процессе самореализачии в спорте.

Эмпирически доказано, что для большинства молодых спортсменов спорт является сферой для самореализации. Их понимание понятия "самореализация" согласуется с классическим его определением. Выяснено, что мотивачия у различных групп спортсменов отличается по содержанию. Мотивационная детерминация самореализированных в спорте волейболистов отражает содержание и характеристики спортивной деятельности.

Ключевые слова: спорт, мотивачия, самореализация, спортивная деятельность, волейбол.

Постановка проблеми. Звертання до емпіричного аналізу феномену самореалізації особистості в спорті в час сьогодення має сенс і він змістотворчий з огляду на ті соціальні зміни, які робляться дійсністю у нових демократичних умовах. Здоровий спосіб життя активно входить в систему життєвоважливих цінностей українців та займає чільне місце в ієрархії ії базових потреб. Життя сучасної людини переконливо доводить, що заняття спортом сьогодні $є$ не лише сферою активності спортсменів-професіоналів, а й невід'ємною ланкою життя кожної психологічно зрілої особистості.

Спортивна діяльність є однією з тих сфер активності людини, де вона здатна проявити власну досконалість, використовуючи фізичні можливості для досягнення високих результатів. Спорт $€$ органічним самій природі людини, що сприяє реалізації в ньому іiі вроджених можливостей та потенцій. Окрім того, спорт відзначається чіткими критеріями оцінки його результатів, вимагає високої активності та чіткого цілепокладання від людини. Він потребує не лише достатнього рівня фізичної, але й психічної готовності особистості, високого самоконтролю та саморегуляції, сформованої волі та резистентності для подолання не лише супротиву сильного суперника, а й власних слабкостей. Спортивна діяльність - універсальна в своїй суті, адже вона гармонійно інтегрує не лише фізичну, а й інтелектуальну, мотиваційну, соціальну сфери особистості, що є гідним підгрунтям для іiї цілісного розвитку та самореалізації. Унікальність спортивної діяльності людини визначаться й тим, що вона не базується на розвитку лише рухових, фізичних здібностей людини, а виконує інші функції в ії онтогенетичному функціонуванні. 3-поміж функціональних аспектів спорту можемо виділити прикладний, який виявляється в підготовці людини до інших видів суспільної діяльності; естетичний, як насолоду від майстерно виконаних рухів та вправ; соціальний, як засіб вербальної та невербальної комунікації та взаємодії, творчий.

Випуск 12, 2019. Збірник наукових праць РДГУ 